\title{
Effectiveness of copper and zinc supplementation in patients treated by nutrition therapy
}

\section{Skuteczność suplementacji miedzią i cynkiem u chorych leczonych żywieniowo}

\author{
Maria Korczak ${ }^{1}$, Urszula Grabowska, ${ }^{2,3}$, Dorota Kozieł¹,3, Stanisław Głuszek1,3 \\ ${ }^{1}$ Clinical Department of General, Oncological, and Endocrine Surgery, Regional Hospital, Kielce, Poland \\ Head of the Department: Prof. Stanisław Głuszek MD, PhD \\ ${ }^{2}$ Central Laboratory, Regional Hospital, Kielce, Poland \\ Head of the Laboratory: Urszula Grabowska PhD \\ ${ }^{3}$ Department of Surgery and Surgical Nursing with Research Laboratory, Institute of Medical Sciences, Faculty of Medicine \\ and Health Sciences, Jan Kochanowski University, Kielce, Poland \\ Head of the Department: Prof. Stanisław Głuszek MD, PhD
}

Key words: malnutrition, nutrition therapy, zinc, copper.

Słowa kluczowe: niedożywienie, leczenie żywieniowe, cynk, miedź.

\begin{abstract}
Introduction: Parenteral nutrition (PN) therapy may be effective only provided that the organism is supplied with all the indispensable components. In clinical practice, the treatment of an undernourished patient requires the introduction of substitution of various nutrients, including such elements as copper and zinc.

Aim of the research: An evaluation of the effectiveness of copper and zinc supplementation in patients receiving short-term parenteral nutrition therapy - lasting up to 10 days, and long-term therapy - for more than 10 days.

Material and methods: The study was conducted in the Clinical Department of Surgery at the Regional Polyclinical Hospital in Kielce. Two study groups were distinguished: group 1 - PN with supplementation up to 10 days, into which were qualified 35 patients (16 females and 19 males; median age 66 years); group 2 - PN with supplementation lasting for more than 10 days, into which were qualified 34 patients ( 15 females and 19 males, median age 59 years), and two control groups. Control group 1 were 20 healthy individuals selected at random from among the medical staff. Control group 2 were patients qualified for planned surgical procedure of gallbladder removal. In order to evaluate the concentration of copper and zinc in patients in the study groups, venous blood was collected prior to the introduction of nutrition, and within 7-day intervals during the parenteral nutrition.

Results: No statistically significant differences were observed between the concentrations of zinc in the blood of patients in study groups 1 and 2. This means that, irrespective of the time of measurement, the zinc concentration in blood was similar. In study group 1 , the mean concentration of copper was higher in the measurement performed after 7 days of PN $(88.48 \mu \mathrm{g} /$ $\mathrm{dl})$, compared to the measurement prior to PN $(82.45 \mu \mathrm{g} / \mathrm{dl})(p=0.028)$. The lowest mean concentration of copper in blood in study group 2 was observed in the measurement prior to the introduction of PN $(71.17 \mu \mathrm{g} / \mathrm{dl})$ and, at the same time, it was lower than the measurements performed after $14(98.16 \mu \mathrm{g} / \mathrm{dl}), 21(96.33 \mu \mathrm{g} / \mathrm{dl})$, and $28(100.03 \mu \mathrm{g} / \mathrm{dl})$ days. A significant increase in the concentration of copper and zinc was observed after 14 days of PN.

Conclusions: based on the results of the analysis performed, it was found that zinc and copper administration in standard $\mathrm{PN}$ doses is sufficient. The concentration of copper remains within reference values; however, it is higher after PN therapy.
\end{abstract}

\section{Streszczenie}

Wprowadzenie: Leczenie żywieniowe pozajelitowe (PN) może być skuteczne tylko pod warunkiem dostarczenia organizmowi wszystkich niezbędnych składników. W praktyce klinicznej terapia niedożywionego chorego wymaga włączenia substytucji różnych substancji odżywczych, w tym mikroelementów, takich jak miedź i cynk.

Cel pracy: Ocena skuteczności suplementacji miedzią i cynkiem u chorych leczonych PN w krótkim (do 10 dni) i długim (powyżej $10 \mathrm{dni}$ ) okresie.

Materiał i metody: Badania przeprowadzono w Klinice Chirurgii Wojewódzkiego Szpitala Zespolonego w Kielcach. Wyodrębniono dwie grupy badane: 1 - PN z suplementacją do 10 dni, do której zakwalifikowano 35 chorych (16 kobiet, 19 mężczyzn, mediana wieku: 66 lat), 2 - PN z suplementacją powyżej 10 dni, do której włączono 34 chorych (15 kobiet, 19 mężczyzn, mediana wieku: 59 lat), oraz dwie grupy kontrolne. 
Wyniki: W grupie badanej 1 średnie stężenie miedzi było większe po 7 dniach PN (88,48 $\mu \mathrm{g} / \mathrm{dl})$ w porównaniu ze stężeniem przed włączeniem PN $(82,45 \mu \mathrm{g} / \mathrm{dl})(p=0,028)$. Najmniejsze średnie stężenie miedzi we krwi w grupie badanej 2 stwierdzono przed wprowadzeniem PN (71,17 $\mu \mathrm{g} / \mathrm{dl})$ i jest ono mniejsze od stężenia oznaczonego po 14 (98,16 $\mu \mathrm{g} / \mathrm{dl}), 21$ (96,33 $\mu \mathrm{g} / \mathrm{dl})$ i $28(100,03 \mu \mathrm{g} / \mathrm{dl})$ dniach PN. Istotny wzrost stężenia miedzi i cynku zaobserwowano po 14 dniach PN.

Wnioski: Na podstawie przeprowadzonej analizy stwierdzono, że suplementacja PN cynkiem i miedzią w standardowych dawkach jest wystarczająca. Stężenie miedzi mieści się w granicach wartości referencyjnych, ale jest większe po leczeniu PN.

\section{Introduction}

Malnutrition is observed in approximately $30-50 \%$ of hospitalised patients, and a considerable number of these patients are already undernourished at admission to hospital [1-3]. In the majority of cases it further deepens during hospitalisation [4, 5]. Malnutrition is defined as a deficiency of supply of energy, proteins, and other nutrients, which exerts a clear, negative effect on the body composition, its functions, and the clinical course of the disease $[6,7]$. The consequences of malnutrition may concern both mental and somatic disorders $[8,9]$, prolonged periods of hospitalisation, and increasing costs $[10,11]$, as well as increasing mortality $[12,13]$.

During the perioperative period, metabolism usually increases by $10 \%$ [14]. Attempts to identify the factors which, during the perioperative period, cause an intensification of stress reactions resulted in reports in which the researchers indicated that even 12hour starvation before surgery brings about metabolic changes that prolong the period of convalescence after non-complicated surgical procedures $[15,16]$. Parenteral nutrition therapy is an important preparation for surgery, and during the post-operative period it enables a quicker transition from the anabolic to the catabolic phase, considerably reducing the possibility of occurrence of sever post-operative complications [17-19]. Parenteral nutrition may be effective only provided that the organism is supplied with all the indispensable components. These are: amino acids, glucose, fat emulsion, electrolytes - sodium $(\mathrm{Na})$, potassium $(\mathrm{K})$, calcium $(\mathrm{Ca})$, magnesium $(\mathrm{Mg})$, phosphorus $(\mathrm{P})$, trace elements, vitamins, and water $[20,21]$. Vitamins and trace elements are important components of all modes of nutrition because they act like co-enzymes and co-factors in many metabolic processes [22-26]. The consequences of severe deficiency of microelements are not perceived instantly because the full clinical image develops over many weeks. Biochemical disorders are manifested within 3-5 days. The syndrome of biological deficiency is observed even earlier. Copper and zinc belong to the group of nutritional microelements, the administration of which is associated with many health benefits. The majority of recommendations concerning the supply of zinc and copper are based on the demand calculated for a healthy individual $[27,28]$. There is a lack of studies comparing the demand for microelements in undernourished patients compared to those who are well nourished. For obvious ethical reasons, no randomised studies have been conducted to evaluate the administration of PN with and without the addition of microelements. The supply of a complete kit of microelements constitutes an integral element of nutritional support [29, 30].

Zinc $(\mathrm{Zn})$ is a necessary trace element, a structural and functional component of approximately 120 enzymes that regulate the basic life processes, including, among others: metabolism of carbohydrates, fats, proteins, amino acids, collagen, and functions of the cell membrane [31]. Its amount in the body of a healthy individual is $2-4 \mathrm{~g}$, of which about $75 \%$ is contained in erythrocytes, muscles, bones, and skin.

In natural conditions, zinc loss takes place mainly with the pancreatic juice into the gastrointestinal tract, from where it is excreted with faeces. Another route is excretion with urine and sweat. The concentration of zinc in serum decreases in acute inflammatory states and after injuries, because of the presence of fistulas, as well as in patients suffering from diarrhoea and cirrhosis of the liver. Zinc deficiency causes typical eczematous changes in the skin, hair loss, impairment of wound healing, and immune disorders [32-35]. Exposure to high doses has a toxic effect. Apart from acute intoxication, long-lasting supplementation of high doses of zinc impairs the absorption of copper. An excess of zinc may cause toxic symptoms: acute - nausea and vomiting, and chronic - in the form of iron deficiency [36, 37].

Copper $(\mathrm{Cu})$ is the component of some proteins, cytochrome oxidase, ceruloplasmin, and other enzymes. It has an anti-oxidative effect. The human body contains $80-200 \mathrm{mg}$ of copper, mainly in the liver, which regulates its distribution, processing, and excretion. Among the symptoms of copper deficiency are mentioned: ischaemia, neutropaenia, cardiac arrhythmia, degenerative changes in the nervous system, and pseudo-scurvy [38-40]. Among the circumstances leading to the accumulation of an excess of copper is impairment of bile flow [41]. Copper shows even greater toxicity than zinc and iron. Its overdosing leads to disorders in the absorption of zinc and iron, as well as other metals. Among the symptoms of acute intoxication are mentioned: nausea, vomiting, acute abdominal pain, diarrhoea, and in chronic intoxication: pharyngitis, bronchitis, and intestinal colic [42].

\section{Aim of the research}

The objective of the study was an evaluation of the effectiveness of copper and zinc supplementation in 
patients receiving short-term parenteral nutrition therapy lasting from 7 to 10 days, and long-term parenteral nutrition therapy for a period longer than 10 days.

\section{Material and methods}

Into the study were qualified patients of both genders who received nutritional therapy in the Clinic of Surgery. The criteria of inclusion into the study with administration of parenteral nutrition were as follows: - age 18 - 85 years, nutritional therapy for $>7$ days;

- high obstruction of the gastrointestinal tract (cancer-related stricture of the oesophagus);

- external gastrointestinal fistulas;

- short bowel syndrome;

- acute pancreatitis;

- inflammatory bowel diseases and multi-organ injury.

Criteria for exclusion:

- age under 18 and over 85 years;

- nutritional therapy for $<7$ days;

- terminal period of a cancerous disease, patients receiving nutritional support.

In all the patients who qualified for the study, the state of nutrition was evaluated, and a kit of measurements of the somatic state was performed: body height, weight, and body mass index (BMI) calculated according to the following formula: $\mathrm{BMI}=$ body weight $(\mathrm{kg}) /$ body height $\left(\mathrm{m}^{2}\right)$.

In each patient, the nutritional status was evaluated using the Nutritional Risk Screening (NRS) 2002, which allows assessment of the four basic factors: dynamics of weight loss, disorders in dietary intake, current body mass index, and the degree of intensification of the disease. Prior to the introduction of nutritional therapy, the following laboratory blood tests were performed: levels of $\mathrm{Na}, \mathrm{K}, \mathrm{Ca}, \mathrm{Mg}, \mathrm{Cl}, \mathrm{P}$, glucose, total protein and albumin, urea, creatinine, triglycerides, cholesterol, bilirubin, C-reactive protein, and the activity of: aspartate aminotransferase, alanine aminotransferase, $\gamma$-glutamyl transferase, and complete blood count. The monitoring of nutrition was carried out by daily clinical examination of the patient, measurement of temperature, fluid balance, assessment of the site of peripheral venous catheter insertion and central venous catheter insertion, and the results of laboratory tests, the frequency of performance of these tests being dependent on the state of the patient and the progress in treatment. During the first days of nutritional therapy the examinations were performed every second day, while during the period of stabilisation - twice a week. In all patients the material for tests - venous blood - was collected prior to the implementation of nutrition, and at 7-day intervals during nutritional therapy.

The duration of parenteral nutrition constituted a determinant to select two basic groups of patients: The patients were divided as follows: group 1 - PN from 7-10 days, 35 patients; group 2 - PN more than 10 days, 34 patients.

According to the adopted criteria, into study group 1 were qualified 35 patients (16 females and 19 males, median age: 66 years). Into study group 2 were qualified 34 patients (15 females and 19 males, median age: 59 years). Control group 1 included 20 healthy, normally nourished individuals (13 females and 7 males, median age: 36 years). Control group 2 were patients qualified for planned surgical procedure of gallbladder removal (27 females and 11 males, median age: 35 years).

The tests were performed in the Diagnostic Laboratory at the Regional Polyclinical Hospital.

In order to determine the concentration of zinc in this procedure, the colorimetric method 5-Br-PAPS was applied without deproteinisation of the sample. The concentrations of zinc 68-107 $\mu \mathrm{g} / \mathrm{dl}$ were adopted as reference values.

Determination of the concentration of copper in serum was done using colorimetric method without deproteinisation of the sample. The concentrations of copper $70-155 \mu \mathrm{g} / \mathrm{dl}$ were adopted as reference values.

\section{Statistical analysis}

Statistical analyses were performed using IBM SPSS Statistics software. Basic descriptive statistics were analysed and the following tests were performed: $t$-Student test for dependent samples, and one-way single factor analyses for dependent and independent samples. The $p$-values $<0.05$ were considered statistically significant.

\section{Results}

Two study groups and two control groups were distinguished in the study. In study group 1, the patients received parenteral nutrition $(\mathrm{PN})$ for up to 10 days, 35 patients (16 females and 19 males, median age: 66 years). In study group 2, PN was applied for longer than 10 days, 34 patients (15 females and 19 males, median age: 59 years). Control group 1 were 20 healthy, normally nourished individuals selected at random from among the medical staff of the Clinic. Control group 2 included 38 patients qualified for planned surgical procedure of gallbladder removal.

In the first measurement of the concentration of copper, no significant differences were observed ( $p>0.05)$, between study group $1(82.45 \mu \mathrm{g} / \mathrm{dl})$, study group 2 (74.12 $\mu \mathrm{g} / \mathrm{dl})$, and control group 1 (74.64 $\mu \mathrm{g} / \mathrm{dl})$.

In control group 2 the mean concentration was the highest $(91.37 \mu \mathrm{g} / \mathrm{dl})(p=0.030$, Figure 1$)$.

In study group 1 the patients receiving parenteral nutrition for up to 10 days, the concentration of copper was higher in the second measurement $(88.48 \mu \mathrm{g} / \mathrm{dl})$, after the implementation of $\mathrm{PN}$, compared to the first measurement $(82.45 \mu \mathrm{g} / \mathrm{dl})$, prior to the implementation of parenteral nutrition $(p=0.028)$. Cohen's $d$ val- 


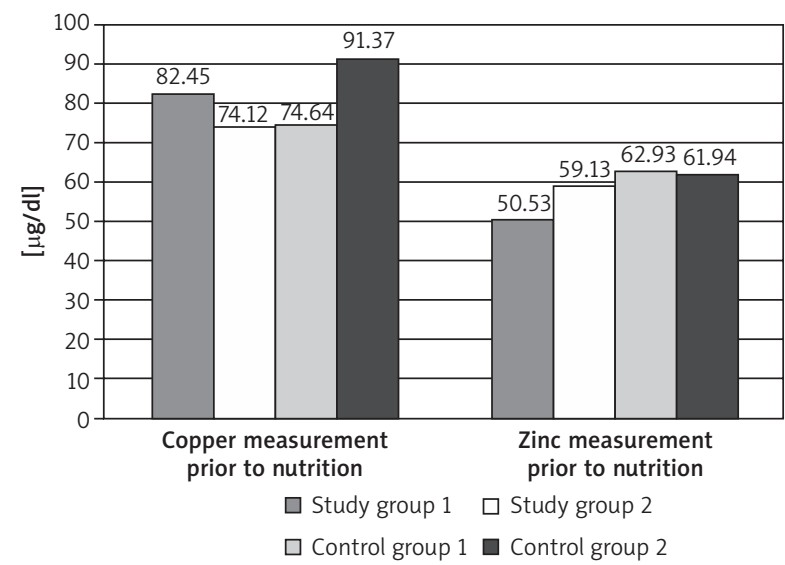

Figure 1. Comparison of mean concentration of copper and zinc in blood of examined patients in the first measurement in study group 1 and 2, and in control group 1 and 2

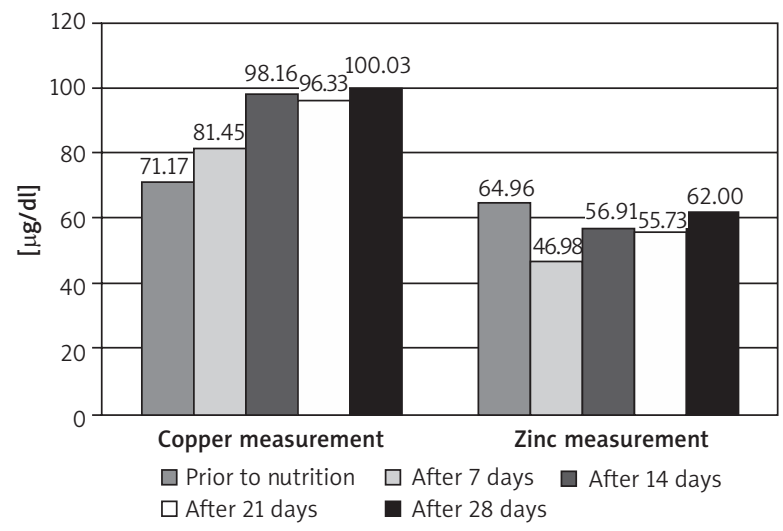

Figure 3. Comparison of mean concentration of copper and zinc in blood in patients in study group 2, in measurement before parenteral nutrition, and after 7, 14, 21, and 28 days of parenteral nutrition

ue (0.395) shows that the strength of the effect of the differences was moderate (Figure 2).

In study group 2 patients who received $\mathrm{PN}$ for longer than 10 days, the mean concentration of copper in blood differed between the first measurement prior to the implementation of $\mathrm{PN}$, and measurements after 14 21 , and 28 days of parenteral nutrition, with the mean values of copper concentrations in measurements performed after 14, 21, and 28 days being similar.

The lowest mean concentration of copper in blood in study group 2 was observed in the measurement prior to the implementation of PN $(71.17 \mu \mathrm{g} / \mathrm{dl})$ and was simultaneously lower than the measurements after $14(98.16 \mu \mathrm{g} / \mathrm{dl}), 21(96.33 \mu \mathrm{g} / \mathrm{dl})$, and $28(100.03 \mu \mathrm{g} / \mathrm{dl})$ days. The concentration of copper significantly increased after 14 days of PN ( $p=0.013$ ) (Figure 3).

The concentration of zinc in patients' blood in the first measurement before implementation of paren-

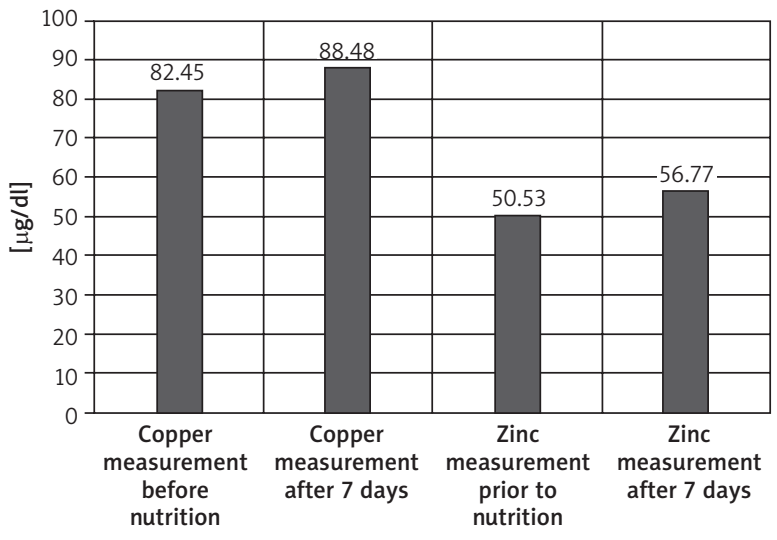

Figure 2. Comparison of mean concentration of copper and zinc in blood of patients examined. Study group 1 in measurement prior to parenteral nutrition, and after 7 days of parenteral nutrition

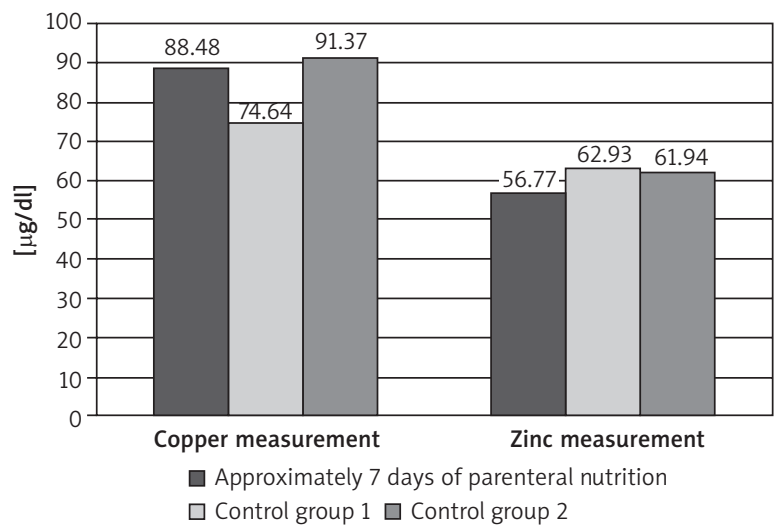

Figure 4. Comparison of mean concentration of copper and zinc in blood of patients in study group 1 and control group 1 and 2

teral nutrition was similar in all groups (Figure 1). In study group 1 , receiving parenteral nutrition for a period up to 10 days, no differences were noted in the measurements of zinc concentration $(p=0.276)$. This means that the patients in study group 1 had a similar concentration of zinc in blood before PN $(50.53 \mu \mathrm{g} / \mathrm{dl})$, and after 10 days of parenteral nutrition $(56.77 \mu \mathrm{g} / \mathrm{dl})$ (Figure 2). In study group 2, in patients who received PN for longer than 10 days, no statistically significant differences were observed between the measurements of zinc levels in blood. This means that irrespective of the measurement time, the concentration of zinc in blood was comparable ( $p=0.528$ ) (Figure 3$)$.

No statistically significant differences in the concentrations of copper and zinc in blood were found in study groups 1 and 2, compared to control groups 1 and 2 , and individual measurements after 7,14 , and 21 days (Figures $4-7)(p>0.05)$. 


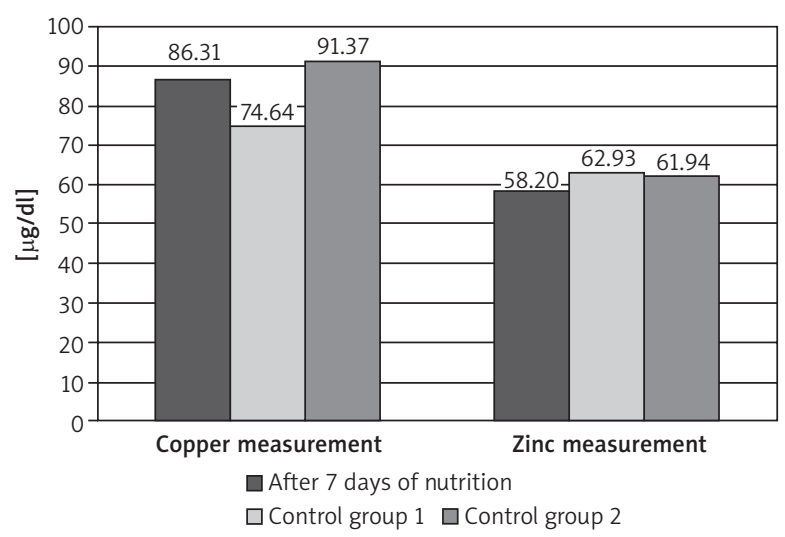

Figure 5. Comparison of mean concentration of copper and zinc in blood of patients from study group 2 after 7 days, and control groups 1 and 2

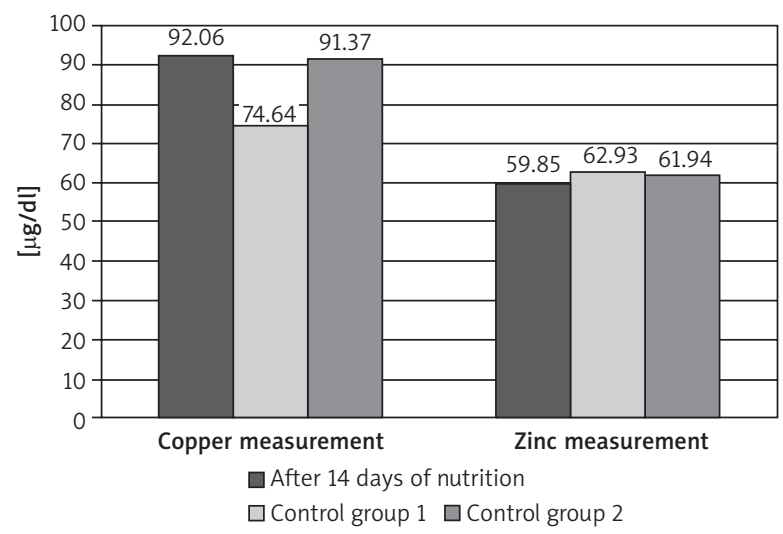

Figure 6. Comparison of mean concentration of copper and zinc in blood of patients from study group 2 after 14 days and control groups 1 and 2

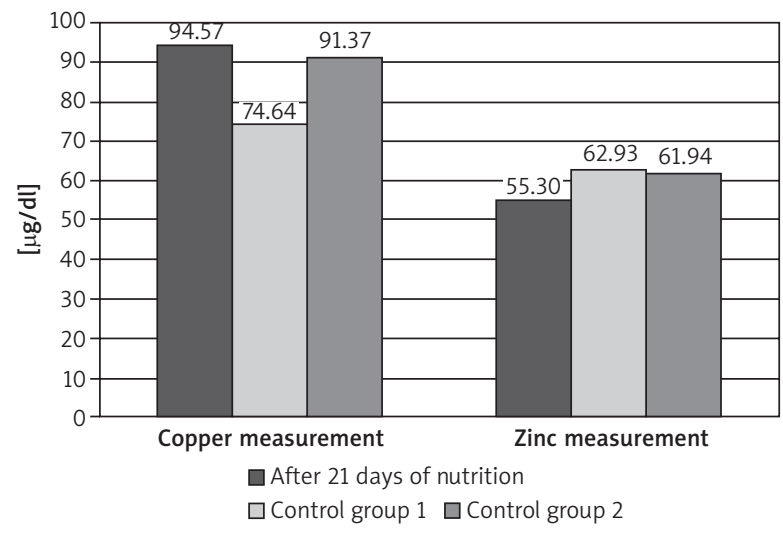

Figure 7. Comparison of mean concentration of copper and zinc in blood of patients from study group 2 after 21 days and control group 1 and 2

\section{Discussion}

In parenteral nutrition, trace elements are usually administered in standard doses [43, 44], irrespective of body weight or the rate of metabolism. The sup- ply of trace elements in PN is managed in two ways. Complex preparations are administered in mixtures that contain in their composition all trace elements that cover the daily demand. Microelements cooperate in the body; therefore, a change in the content of a single component causes a disturbance of balance. The principle of applying a kit of microelements instead of single elements is based on the observation of biochemical mechanisms of the effect of the endogenous antioxidant network [45]. With the second method of supplying inorganic micro-components single-component preparations, corrective with individual elements, are administered in the case of detection of deficiency [46-48]. This requires more time, incurs higher costs, and also increases the risk of making mistakes while determining doses. At present, in many countries it is not possible to determine a balanced supplementation scheme of products containing single compounds. It is important to develop new basic preparations that contain many components, to which additional microelements could be attached in the case of patients with an increased loss, e.g. of zinc. The demand for trace elements reported by various researchers shows considerable differences, and is subject to constant corrections in the course of closer recognition of their importance, metabolism, routes of excretion, etc.

The majority of preparations containing microelements for PN have been prepared for patients in a stable state. These solutions transpire to be properly balanced for chronically ill patients from the aspect of the majority of microelements.

In light of the results obtained, the effectiveness of zinc supplementation for PN in standard doses was successfully confirmed. No differences were found in the mean concentration of zinc in blood prior to and after the introduction of PN. While analysing the results in study group 1 and 2, the effectiveness of zinc supplementation in standard doses was observed, which was confirmed by the studies of Howard et al. [46]. These studies evaluated the concentration of iron, zinc, copper, manganese, chromium, and selenium in tissues collected during the post-mortem examination of 8 persons with short bowel syndrome, in whom the mean duration of PN was 14 years. The results showed normal values of selenium, iron, and zinc, but elevated values of manganese, copper, and chromium. The introduction of parenteral nutrition provided the researchers with a rare opportunity to recognise and understand the role of individual trace elements. The syndromes and diseases as a consequence of their deficiency have been described, and doses indispensable for any human deprived of normal nutrition have been determined. Deficit of micro-components may lead to clear clinical consequences [49]. Trace elements are very important in parenteral nutrition, although the deficiency of some of them manifest after many 
months, or even years, of administration of PN deprived of an individual element. This, however, does not concern the deficiency of zinc and copper, which manifest as early as within the first weeks of nutrition and are of a great clinical importance [50]. The demand during the period of disease, stress, and after injury is difficult to establish because the majority of recommendations concerning the supply are based on the demand calculated for a healthy individual. The supply of trace elements should enable the maintenance of an optimum function of tissues, and prevent deficiencies. In the case of total parenteral nutrition there is a consensus that the daily supplementation of microelements should be applied [51, 52]. According to the guidelines by the American Agency for Food and Drug Administration (FDA), the daily demand for zinc and copper administered parenterally to adults is: for copper $0.3-0.5 \mathrm{mg}$, and for zinc $2.5-5 \mathrm{mg}$ [53]. The dosing of trace elements in PN should be individualised and adjusted to the clinical state of an individual patient [54-56]. The importance of microelements for health is undisputed, e.g. zinc is indispensable in the form of catalytic ion in structural and regulatory proteins. Their importance for health is increasingly appreciated, and deficiency may play an important role in the development of a disease $[57,58]$. Preparations designed for PN do not contain microelements due to the stability of the solution, which requires separate prescribing of these substances, while they are omitted in as many as 50\% of patients receiving parenteral nutrition [59]. The basic feature of a necessary trace element is that its lack or inadequate supply in a diet are associated with repeatable structural or biochemical changes, which are reversed after its supplementation. The determination of an optimum supply of nutritional micro-components is far from being perfect. It is possible to perform a complex evaluation of individual demand based on the demand in the state of health. It has been proven that the supplementation of trace elements in the case of application of preparations currently available on the market, in the majority of situations, is sufficient to prevent the development of the states of deficiency. However, determination of the amount of supply of microelements that would provide an optimum functioning of tissues remains imprecise. The lowest mean concentration of copper in blood in study group 2 was observed in the measurement performed prior to the introduction of PN. The concentration of copper significantly increased after 14 days of PN. The results of studies indicate that the mean concentration of copper remained on a constant level after 14, 21, and 28 days. Such a supplementation of microelements transpired to be adequately balanced for patients from study group 1 and 2, from the aspect of copper. In turn, Chen et al. [60] evaluated changes in the concentrations of zinc and copper in 17 patients who received PN for up to 89 days. The mean concentration of zinc in serum considerably decreased after 4 weeks of treatment in the group without zinc supplementation, compared to the level before treatment, and in the second group. The concentration of copper significantly decreased in both groups. These results show that the decrease in the content of zinc and copper is serum is commonly observed in PN while applying solutions without supplementation of trace elements. In the study by Itokawa [61], the symptoms of deficiency of trace elements developed in patients receiving long-term $\mathrm{PN}$ not containing zinc occurred in the form of a wet dermatitis. In this case, the concentration of zinc was very low. The response to intravenous treatment with zinc was striking. The deficiencies of copper in the form of anaemia and neutropaenia disappeared after the supplementation with this element.

In clinical practice the treatment of a severely undernourished patient requires the administration of various nutritional substances, including such microelements as zinc and copper. Their deficiency, as well as excess, are dangerous for a patient [62]; hence, an evaluation of the effectiveness of supplementation during nutritional therapy of severely ill patients is very important. Even the slightest deficiency of one nutrient may be perceived as a failure in nutritional care, which should satisfy the total and obvious demands of each organism [63-65]. Ethical reasons do not allow the performance of randomised studies that would evaluate the use of PN with and without the addition of microelements.

In the literature there are a wide variety of views concerning the composition of preparations for PN. The presented study confirmed that the supplementation of microelements in standard doses is justified in the case of zinc and copper. This is an important therapeutic management because it enables the balance or reduction of deficiency of nutrients, and allows an attempt to restore normal concentrations.

These solutions transpired to be adequately balanced from the aspect of content of zinc and copper in the examined group of patients, which was confirmed in the study evaluating the concentration of zinc in study group 1 and 2 . In both groups, no significant increase in the concentrations of copper and zinc were obtained.

\section{Conclusions}

The results of the presented study allow the drawing of the following conclusions: 1) substitution of zinc in nutritional therapy is sufficient because the mean concentrations remain within the range of reference values; 2) an upward tendency was observed in concentrations of copper within short- and longterm $\mathrm{PN}$; however, it remained within the range of reference values, which indicated the necessity for the modification of supplementation. 


\section{Conflict of interest}

The authors declare no conflict of interest.

\section{References}

1. Dzieniszewski J, Jarosz M, Szczygieł B, Długosz J, Marlicz K, Linke K, Lachowicz A, Ryzko-Skiba M, Orzeszko M. Nutritional status of patients hospitalized in Poland. Eur J Clin Nutr 2005; 59: 552-60.

2. Szczygieł B. Niedożywienie związane z chorobą. Występowanie. Rozpoznanie. PZWL, Warsaw 2012.

3. Ljungqvist O, van Gossum A, Sanz ML, de Man F. The European fight against malnutrition. Clin Nutr 2010; 29 149-50.

4. Council Of Europe. Food and nutritional care in hospital. How to prevent undernutrition. Report and guidelines. Provisional edition. April 2001

5. Szczygieł B. Niedożywienie szpitalne w Europie. Występowanie, przyczyny, zapobieganie. Wytyczne Rady Europy. Żyw Człow Metabol 2004; 31: 35-42.

6. Lochs H, Allison SP, Meier R, Pirlich M, Kondrup J, Schneider S, van den Berghe $G$, Pichard C. Introductory to the ESPEN guidelines on enteral nutrion: terminology, definitions and general topics. Clin Nutr 2006; 25: 180-195.

7. Bozzetti F. A new classification of cancer cachezia. Postępy żywienia klinicznego. PZWL, Warsaw 2008; 3: 11-4.

8. Pertkiewicz M, Orawczyk T, Korta T. Definicje i opisy leczenia żywieniowego przekazane do Narodowego Funduszu Zdrowia. Post Żyw Klin 2007; 6: 4-8.

9. Kuzu MA, Terzioğlu H, Genç V, Erkek AB, Ozban M, Sonyürek $\mathrm{P}$, Elhan $\mathrm{AH}$, Torun N. Preoperative nutritional risk assessment in predicting postoperative outcome in patients undergoing major surgery. World J Surg 2006; 30: 378-90.

10. Elia M. Nutrition and health economics. Nutrition 2006; 22: $576-8$.

11. Álvarez-Hernández J, Planas Vila M, León-Sanz M, García de Lorenzo A, Celaya-Pérez S, García-Lorda P, Araujo K, Sarto Guerri B; PREDyCES researchers. Prevalence and costs of malnutrition in hospitalized patients; the PREDyCES Study. Nutr Hosp 2012; 27: 1049-59

12. Nitenberg G, Raynard B. Nutritional support of the cancer patient: issues and dilemmas. Crit Rev Oncol Hematol 2000; 34: 137-68

13. Ziegler T. Parenteral nutrition in the critically ill patient N Engl J Med 2009; 361: 1088-97.

14. Kinney M, Duke J Jr, Long CL, Gump FE. Tissue fuel and weight loss after injury. J Clin Path 1970; 4 (suppl 23): 65-72.

15. Ljungqvist $\mathrm{O}$, Nygren J, Thorell A. Modulation of postoperative insulin resistance by pre-operative carbohydrate loading. Pro Nutr Soc 2002; 61: 329-36.

16. Ljungvist O, Nygren J, Thorell A, Brodin U, Efendic S. Preoperative nutrion elective surgery in the fed or the overnight fasted state. Clin Nutr 2001; 20: 167-71.

17. Pertkiewicz M, Kunecki M. Spojrzenie na żywienie pozajelitowe i dojelitowe. Post Żyw Klin 2010; 1: 17-22.

18. Słowiński R, Słowińska M. Żywienie wspomagające odporność u chorych chirurgicznych - jeżeli tak, to dlaczego należy je stosować? Post Żyw Klin 2006; 2: 27-31.

19. Głuszek S, Korczak K, Kot M, Matykiewicz J, Kozieł D. Przetoki przewodu pokarmowego - problem wciąż aktualny. Pol Przegl Chirur 2011; 83: 53-69.
20. Pertkiewicz M, Korta T, Książyk J, Łyszkowska M, Matczuk M, Spodaryk M, Kamocki Z, Zalewski B, Kalaciński J, Orawczyk T, Karwowska K, Skowrońska-Piekarska U, Kunkel M, Ciszewska-Jędrasik M, Majewska K, Urbanowicz K, Kłęk S, Milewczyk M, Kawecki K, Paluszkiewicz P, Bogucki K, Cebulski W, Rudzki S. Standard żywienia pozajelitowego i dojelitowego. Warszawa, PZWL 2005.

21. Głuszek S, Korczak M. Postępowanie w szczególnie trudnych przetokach pooperacyjnych w świetle aktualnych rekomendacji. Studia Medyczne 2009; 14: 13-20.

22. Davis AT, Franz FP, Courtnay DA, Ullrey DE, Scholten DJ, Dean RE. Plasma vitamin and mineral status in home parenteral nutrition patients. JPEN J Parenteral Enteral Nutr 1987; 11: 480-5.

23. Marinier E, Gorski AM, de Courcy GP, Criqui C, Bunodiere M, Christides JP, Causse MB, Brion F, Ricour C, Navarro J. Blood levels of waters-soluble vitamins in pediatric patients on total parenteral nutrition using a multiple vitamin preparation. JPEN J Parenteral Enteral Nutr 1989; 13: $176-84$

24. Labadarios D, O’Keefe SJ, Dicker J, Van Stuijvenberg L, Visser L, Louw ME, Shephard GS. Plasma vitamin level in patients on prolonged total parental nutrition. JPEN J Parenter Enteral Nutr 1988; 12: 205-11.

25. Favier M, Hininger J. Trace elements: zinc, copper, elenium, chromium. Consequences of a deficiency, of excessive trace elements, and value of systematic supplementation. J Gynecol Obstet Biol Reprod 1997; 26: 109-14.

26. Shenkin A. Trace elements and vitamins in adult intravenous nutrition. In: Clinical nutrition: parenteral nutrition. $3^{\text {rd }}$ ed. Rombeau JL, Rolandelli RH (eds). W. B. Saunders Co., Philadelphia 2001; 60-79.

27. Deutsche Gesellschaft fur Ernahrung. Referenzwerte fur die Nahrstoffzufuhr. Umschau-Braus-Verl, Frankfurt am Main: 2000

28. Koretz RL, Lipman TO, Klein S; American Gastroenterological Association. AGA technical review on parenteral nutrition. Gastroenterology 2001; 121: 970-1001.

29. Leichtmanns BS, Sitrin MD. Update on trace elements. Compr Ther 1991; 17: 42-8.

30. ESPEN. Basics in clinical nutrition. $3^{\text {rd }}$ ed. Galen, Prague 2004.

31. Kyle U, Jetzer G, Schwarz G, Pichard C. Utilization of total patenteral nutrition in a university hospital: a prospective quality control study in 180 patients. Clin Nutr 1997; 17: 48.

32. Mohammad MK, Zhou Z, Cave M, Barve A, McClain CJ. Zinc and liver disease. Nutr Clin Pract 2012; 27: 8-20.

33. Finner AM. Nutrition and hair: deficiencies and supplements. Dermatol Clin 2013; 31: 167-72.

34. Prasad AS. Discovery of human zinc deficiency: 50 years later. J Trace Elem Med Biol 2012; 26: 66-9.

35. Prasad AS. Discovery of human zinc deficiency: its impact on human health and disease. Adv Nutr 2013; 4: 176-90.

36. Szczygieł B, Socha J. Żywienie pozajelitowe i dojelitowe w chirurgii. PZWL, Warsaw 1994; 70-1.

37. Plum LM, Rink L, Haase H. The essential toxin: impact of zinc on human health. Int Environ Res Public Health 2010; 7: 1342-65.

38. Sampson B, Constantinescu MA, Chandarana I, Cussons PD. Severe hypocupraemia in a patient with extensive burn injuries. Ann Clin Biochem 1996; 33: 462-4. 
39. Hoyle GS, Schwartz RP, Auringer ST. Pseudoscurvy caused by copper deficiency. J Pediatr 1999; 34: 161-4.

40. Scheiber I, Dringen R, Mercer JF. Copper: effects of deficiency and overload. Met Ions Life Sci 2013; 13: 359-87.

41. Beshgetoor D, Hambidge M. Clinical conditions altering copper metabolism in humans. Am J Clin Nutr 1998; 67 (5 Suppl): 1017-21.

42. Chan S, Gerson B, Subramaniam S. The role of copper, molybdenum, selenium, and zinc in nutrition and health. Clin Lab Med 1998; 18: 673-85.

43. Leung FY. Trace elements in parenteral micrnutrition. Clin Biochem 1995; 28: 561-6.

44. Biesalski HK, Bischoff SC, Boehles HJ, Muehlhoefer A; Working group for developing the guidelines for parenteral nutrition of The German Association for Nutritional Medicine. Water, electrolytes, vitamins and trace elements. Guidelines on Parenteral Nutrition, Chapter 7. Ger Med Sci 2009; 7: doc21.

45. Abdalian R, Fernandes G, Duerksen D, Jeejeebhoy KN, Whittaker S, Gramlich L, Allard JP. Prescription of trace elements in adults on home parenteral nutrition: current practice based on the Canadian Home Parenteral Nutrition Registry. JPEN J Parenteral Enteral Nutr 2013; 37: 410-5.

46. Berger M. Key vitamins and trace elements in the critical ill. Nestle Nutrition Workshop Series Clinical Performance Program 2003; 8: 99-117.

47. Ciszewska-Jędrasik M, Pertkiewicz M. Mieszaniny do żywienia pozajelitowego. Standardy postępowania i zalecenia dla farmaceutów. PZWL, Warsaw 2004; 95.

48. Pertkiewicz M, Szczygieł B, Sobotka L. Skład mieszanin odżywczych i program żywienia pozajelitowego. Podstawy żywienia klinicznego. PZWL, Warsaw 2007; 255-61.

49. Howard L, Ashley C, Lyon D, Shenkin A. Autopsy tissue elements in 8 long-team parenteral nutrition patients who received the current U.S. Food and Drug Administration formulation. JPEN J Parenter Enteral Nutr 2007; 31: 388-96.

50. Pramyothin P, Kim DW, Young LS, Wichansawakun S, Apovian CM. Anemia and leukopenia in long-term parenteral nutrition patient during a shortage of parenteral trace elements products in the United States. JEPN J Parenter Enteral Nutr 2013; 37: 425-9.

51. Shenkin A. The key role of micronutrients. Clin Nutr 2006; 25: 1-13.

52. Braga A, Ljungvist P. Wytyczne ESPEN dotyczące żywienia pozajelitowego: chirurgia. Post Żyw Klin 2011; 2: 7-20.

53. Bozzetti F, Arends J, Lundholm K, Micklewright A, Zurcher G, Muscaritoli M; ESPEN. ESPEN Guidelines on Parenteral Nutrition: non-surgical oncology. Clin Nutr 2009; 28: $445-54$

54. Food and Drug Administration (FDA). Parenteral multivitamin products; drugs for humana use; drug efficacy study implementation; amendment. Federal Register 2000; 65: 21200-1.

55. Btaiche IF, Carver PL, Welch KB. Dosing and monitoring of trace slements in long-term home parenteral nutrition patients. JPEN J Parenter Enteral Nutr 2011; 35: 736-47.

56. Howard L, Ashley C, Lyon D, Shenkin A. Autopsy tissue trace elements in 8 long-term parenteral nutrition patients who received the current U.S. Food and Drug Administration formulation. JPEN J Parenter Enteral Nutr 2007; 31: 388-96
57. Lowry SF, Goodgame JT Jr, Smith JC, Maher MM, Makuch RW, Henkin RI, Brennan MF. Abnormalities of zinc and cooper during total parenteral nutrition. Ann Surg 1979; 189: 120-8.

58. Chasapis CT, Loutsidou AC, Spiliopoulou CA, Stefanidou ME. Zinc and human health: an update. Arch Toxicol 2012; 86: 521-34.

59. Stefanidou M, Maravelias C, Dona A, Spiliopoulou C. Zinc: a multipurpose trace element. Arch Toxicol 2006; 80: 1-9.

60. Chen W, Chiang TP, Chen TC. Serum zinc and copper during long-team total parenteral nutrition. J Formos Med 1991; 90: 1075-90.

61. Shenkin A, Popiel Z. Funkcje fizjologiczne i stany niedoborowe pierwiastków śladowych. Podstawy żywienia klinicznego. Postępy żywienia klinicznego. PZWL, Warsaw 2008; 93.

62. Itokawa Y. Trace elements in long-term total parenteral nutrition. Nihon Rinsho 1996; 54: 172-8.

63. Shenkin A. The role of vitamins and minerals. Clin Nutr 2003; 22 Suppl 2: 29-32.

64. Shenkin A. Micronutrients and outcome. Nutrition 1977; 13: 825-8.

65. Shenkin A. Trace elements and vitamins in parenteral and enteral nutrition. Basics in clinical nutrition. ESPEN 2000.

\section{Address for correspondence:}

\section{Maria Korczak}

Clinical Department of General, Oncological, and Endocrine Surgery

Regional Hospital

ul. Grunwaldzka 45, Kielce, Poland

Phone: +48 536549583

E-mail: marcysia65@vp.pl 